\title{
Chemical properties, microbiological quality and sensory evaluation of chicken and duck liver paste (foie gras)
}

\author{
By Ferial M. Abu-Salem and Esmat A. Abou Arab
}

\author{
Department of Food Technology, National Research Centre, Dokki, Cairo, Egypt \\ ( ${ }^{\star}$ Corresponding author: ferial_mas@yahoo.com)
}

\section{RESUMEN}

Propiedades químicas, microbiológicas y evaluacion sensorial de pasta de hígado de pollo y pato (foie gras).

La pasta de hígado o foie gras es un término francés, que significa "hígado graso" y es tradicionalmente producido de oca y pato. El pollo también es usado en la manufactura de foie gras. El presente trabajo estudia las propiedades y calidad de hígado crudo de pollo y pato en comparación con la manufactura de pasta de hígado (foie gras). El higado de pollo crudo contienen $24.60 \%$ de proteina, $6 \%$ de grasa, $1.40 \%$ de ceniza y $66.80 \%$ de humedad. Los valores promedios de minerales fueron $83.65,50.75,5.29,1.15,0.154$, $0.683,0.317$ y $0.066 \mu \mathrm{g} / \mathrm{g}$ para $\mathrm{Fe}, \mathrm{Zn}, \mathrm{Cu}, \mathrm{Mn}, \mathrm{Cd}, \mathrm{Pb}, \mathrm{Ni}$ y $\mathrm{Cr}$, respectivamente. El procesado de la pasta de hígado (foie gras) cambio la composición del hígado crudo, debido a una pérdida de humedad, a una libreación de grasa, y a la adicción de mantequilla como fuente de grasa. La pasta de hígado de pollo contiene $27.8 \%$ de humedad, $10.1 \%$ de proteina, $58.2 \%$ de grasa y $0.8 \%$ de ceniza. El contenido mineral fue $68.90,40.50,1.60,1.1,0.08,0.22,0.04$ and $0.04 \mu \mathrm{g} / \mathrm{g}$ de $\mathrm{Fe}, \mathrm{Zn}, \mathrm{Cu}, \mathrm{Mn}, \mathrm{Cd}, \mathrm{Pb}, \mathrm{Ni}$ y $\mathrm{Cr}$, respectivamente. La evaluación química, microbiológica y sensorial de la pasta de hígado (foi gras) manufacturada de hígado crudo, y preservada con $500 \mathrm{ppm}$ de ácido benzoico (BA) o ácido sórbico (SA) y una mezcla de 500 pm de ambos (BA + SA) con o sin pasterización a $85{ }^{\circ} \mathrm{C}$, fue estudiada durante un periodo de almacenamiento de 9 días a $4{ }^{\circ} \mathrm{C}$. Presumiblemente, la mezcla de pasta de hígado (foi gras) de pollo con 500 ppm de $\mathrm{BA}+\mathrm{SA}$ y pasterizado el producto a $85{ }^{\circ} \mathrm{C}$ puede ser recomndada debido a sus bajos valores de ácido tiobarbitúrico (TBA), de nitrógeno volatil total (TVN), de valor de peróxidos (PV), de ácidos grasos libres (FFA) y del valor de saponificación; y por tanto por inhibir la oxidación lipídica y prevenir la racidez en un periodo de nueve dias almacenados a $4{ }^{\circ} \mathrm{C}$. Este valor es tambien recomendado como agente conservante para inhibir del derioro bacteriano de la pasta de hígado de pollo (foi gras). La evaluación sensorial mostró que la pasta de hígado de pollo fue mucho más aceptable desde un punto de vista de sabor, olor, apariencia, color y textura. En comparación con la pasta de hígado de pato, los resultados prueban que no se observan diferencias significativas entre la pasta de hígado de pollo y la pasta de hígado de pato.

PALABRAS CLAVE: Evaluación microbiológica - Evaluación química - Evaluación sensorial - Hígado crudo de pollo - Pasta de hígado de pato - Pasta de hígado de pollo (foi gras) - Preservación.

\section{SUMMARY}

Chemical Properties, Microbiological Quality and Sensory Evaluation of Chicken and Duck Liver Paste (foie gras).

Liver paste or foie gras, which is a French term meaning "fatty liver", was produced traditionally from goose and duck. Chickens are also used in the making of foie gras. The present study deals with the properties and quality of raw chicken and duck liver in comparison with manufactured liver paste (foie gras). Raw chicken liver contained $24.60 \%$ protein, $6.00 \%$ fat, $1.40 \%$ ash, and $66.80 \%$ moisture. The average mineral values were $83.65,50.75,5.29,1.15,0.154,0.683,0.317$ and 0.066 $\mu \mathrm{g} / \mathrm{g}$ of $\mathrm{Fe}, \mathrm{Zn}, \mathrm{Cu}, \mathrm{Mn}, \mathrm{Cd}, \mathrm{Pb}, \mathrm{Ni}$, and $\mathrm{Cr}$, respectively. The processing of liver paste (Foie gras) changed the composition of raw liver due to a loss in moisture, a release of fat and the addition of butter as a fat source. Chicken liver paste contained $27.8 \%$ moisture, $10.1 \%$ protein $58.2 \%$ fat, and $0.8 \%$ ash. Mineral contents were 68.90 , $40.50,1.60,1.1,0.08,0.22,0.04$ and $0.04 \mu \mathrm{g} / \mathrm{g}$ of $\mathrm{Fe}, \mathrm{Zn}$, $\mathrm{Cu}, \mathrm{Mn}, \mathrm{Cd}, \mathrm{Pb}, \mathrm{Ni}$, and $\mathrm{Cr}$, respectively. The chemical, microbiological and sensory evaluation of liver paste (foie gras) manufactured from raw liver and preserved by the addition of $1000 \mathrm{ppm}$ of both benzoic acid (BA) or sorbic acid (SA) and a mixture of $500 \mathrm{ppm}$ of both BA plus SA with or without pasteurization at $85^{\circ} \mathrm{C}$ were studied during the storage period for 9 days at $4{ }^{\circ} \mathrm{C}$. Presumably, the mixing of liver paste (Foie gras) from chicken liver with 500 ppm of both BA plus SA and pasteurizing the product at $85{ }^{\circ} \mathrm{C}$ could be recommended for lowering thiobarbituric acid (TBA), total volatile nitrogen (TVN), peroxide value (PV), free fatty acid (FFA), ammonia, saponification value and hence for inhibiting lipid oxidation and preventing rancidity to an extent up to nine days of refrigerated storage $\left(4^{\circ} \mathrm{C}\right)$. This level is also recommended as a preservative agent to inhibit the bacterial deterioration of chicken liver paste (Foie gras). A sensory evaluation showed that liver paste from chicken was very acceptable from the standpoint of taste, odor, appearance, color and texture. In comparison to liver paste from duck, the results proved that no significant differences were observed between the liver paste from chicken and duck liver paste.

KEY-WORDS: Chemical evaluation - Chicken liver paste (foie gras) - Duck liver paste - Microbiological evaluation - Preservation - Raw chicken liver - Sensory evaluation. 


\section{INTRODUCTION}

Liver paste or foie gras, which is a French term meaning "fatty liver", is a delicate rosy color with a mottling of beige. The flavor is extraordinarily rich and the texture silky smooth (Epicurious Food Dictionary, 1995). Four grades of traditional gastronomic "foie gras" are commercially available (El- Moueffak et al., 1995). Fresh (cold storage for a few days, mainly for restaurants), half cooked (shelf-life at $4{ }^{\circ} \mathrm{C}$, less than 42 days), pasteurized (shelf-life up to 6 months at $+4^{\circ} \mathrm{C}$ ), and sterilized (room temperature storage, up to several years). Each grade corresponds to a particular standard of quality of this food, with typical sensory evalution and specific processing.

The fatty liver, internationally called "foie gras", was produced traditionally from geese. However, in recent years there has been a widespread change to the use of ducks rather than geese, mainly for financial reasons (SCAH, 2005). Chickens are also used in the making of foie gras (Epicurean Com, 2005). However, there is no available data concerning liver paste from chicken liver. Thus the aim of this study was to investigate the chemical, microbiological, and sensory evaluation of chicken and duck liver paste as fresh pasteurized products.

\section{MATERIALS AND METHODS}

\subsection{Materials}

Chicken and duck livers were purchased from local market. Livers of optimum and homogeneous quality were selected, the main lobe was cut off and the liver was wrapped in polyethylene bags. The sample lobes were mixed and divided into bags. The liver to be used in processing was frozen at $-18{ }^{\circ} \mathrm{C}$ for one week.

\subsection{Preparation of liver paste (foie gras) from chicken and duck livers}

Chicken and duck liver paste (foie gras) was prepared according to the method of (Guy et al., 1991) as follows:

The liver samples $(10 \mathrm{~kg})$ were thawed at $2{ }^{\circ} \mathrm{C}$, soaked in water and allowed to reach room temperature for easier handling so that veins and connective tissue could be removed. Liver samples were placed in wire baskets and cooked in water for approximately $30 \mathrm{~min}$. The yield of the processed liver was $6.5 \mathrm{~kg}$ from the raw weight (10 $\mathrm{kg}$ ). Onion cut in small pieces and cardamon in cheesecloth were added to the liver during cooking. $3.5 \mathrm{~kg}$ butter and $2 \%$ salt were added to cooked chicken liver and it was minced for approximately 5 min until the ingredients were uniformly distributed to liver pieces using a rapid meat chopper which operates at speeds up to $3000 \mathrm{rpm}$. Dry ice was added to keep the liver temperature down and the mixture was blended for approximately $1-2 \mathrm{~min}$. to assure the proper distribution of salt and flavoring and also to increase the binding capacity of the soluble proteins in the mixture. The liver paste (foie gras) was packed in jars and used for the different treatments.

\subsection{Experimental design}

Chicken liver paste (foie gras) was manufactured from raw liver and preserved by the addition of 1000 ppm of both benzoic acid (BA) or sorbic acid (SA) and a mixture of $55 \mathrm{ppm}$ of both BA plus SA with or without pasteurization at $85^{\circ} \mathrm{C}$ and later stored for 3,6 , and 9 days at $4{ }^{\circ} \mathrm{C}$.

\subsection{Chemical analysis}

Samples were analyzed chemically and microbiologically before and after treatments and during storage periods. A sensory evaluation was also carried out .

Moisture, protein, fat, ash, total volatile nitrogen (TVN), ammonia, peroxide value (PV), free fatty acid (FFA) and saponification value (SV) were determined according to the methods described in the (AOAC, 1995). Thiobarbituric acid (TBA) value was colorimetrically measured at $538 \mathrm{~nm}$ as mentioned by (Pearson, 1976). The results were expressed as $\mathrm{mg}$ malonaldehyde/kg sample. Minerals were measured by Atomic Absorption Spectrophotometry (Perkin-Elmer 2380). Iron (Fe) was measured at $248.3 \mathrm{~nm}$; copper (Cu) at 324.8 $\mathrm{nm}$; zinc $(\mathrm{Zn})$ at $319.9 \mathrm{~nm}$; cadmium (Cd) at 228.8; lead $(\mathrm{pb})$ at $217.0 \mathrm{~nm}$; Nickel $(\mathrm{Ni})$ at 232.0 and chromium $(\mathrm{Cr})$ at $240.7 \mathrm{~nm}$ with hollow cathode lamps according to (AOAC, 1995).

\subsection{Microbiological analysis}

Samples of liver paste (foie gras) pasteurized and unpasteurized were bacteriologically investigated. Twenty-five gram samples of each of the test samples were suspended in $225 \mathrm{ml}$ of peptone water $(0.1 \%)$ under aspectic conditions. A serial decimal dilution was made using the same medium and plated onto growth media in duplicate. Microbial groups (Aerobic bacteria, Staphylococci, Salmonella spp., coliform bacteria, molds and yeasts) were determined according to the American Public Health Association for foodstuff examination (APHA, 1992).

\subsection{Sensory analysis}

Sensory characteristics of samples (foie gras from chicken and duck livers) were investigated by 10 panelists to evaluate taste, odor, appearance, color, texture and overall acceptability on a 10-point scale where (10) is the best and (1) is the lowest. Three replicates of each sample (chicken and duck livers) were submitted to the sensory analysis. Chicken liver paste was divided into two parts. The first one preserved by benzoic acid (BA) and/ 
or sorbic acid (SA) and pasteurized at $85{ }^{\circ} \mathrm{C}$. The second part preserved by $\mathrm{BA}$ and/or SA, but not pasteurized. The two parts were stored for nine days at $4{ }^{\circ} \mathrm{C}$.

\subsection{Statistical analysis}

Data were subjected to a statistical analysis using a computerized analysis of variance and Duncan's multiple range test procedures with (SAS, 1998). All values are the mean of three replicate analyses.

\section{RESULTS AND DISCUSSION}

The composition of raw chicken liver and chicken liver paste (foie gras) product manufactured from raw liver were studied (Table 1). The raw liver samples were rich in protein which contain a mean value of $24.60 \%$. The fat content, ash and moisture were 6.00 and $1.40 \%$ and $66.80 \%$ respectively. Minerals (which accumulate in the liver $\mathrm{Zn}, \mathrm{Cu}$, $\mathrm{Fe}, \mathrm{Mn}, \mathrm{Cd}, \mathrm{Pb}, \mathrm{Ni}$ and $\mathrm{Cr}$ ) (Sola et al., 1997) were also determined. The results obtained show that raw chicken liver contained higher concentrations of $\mathrm{Fe}(83.65 \mu \mathrm{g} / \mathrm{g})$ and $\mathrm{Zn}(50.75 \mu \mathrm{g} / \mathrm{g})$. Regarding $\mathrm{Cu}$, the level was $(5.29 \mu \mathrm{g} / \mathrm{g})$, followed by $\mathrm{Mn}(1.15$ $\mu \mathrm{g} / \mathrm{g})$. Hecht (1996) reported that if Cu-enriched feeds are used, the $\mathrm{Cu}$ concentration increases in liver. On the other hand, the other metals, $\mathrm{Cd}, \mathrm{Pb}$, $\mathrm{Ni}$ and $\mathrm{Cr}$ were detected in lower levels which were recorded at $0.154,0.683,0.317$, and $0.066 \mu \mathrm{g} / \mathrm{g}$, respectively. The difference in the concentrations of metals probably results from different diets (AbouArab, 2001). Blum (1997) reported that the liver has a composition which does not depend on the length of force-feeding period but only on its weight. Mean values found in the literature are 2.9, 190.2, 11.0, and $93.3 \mu \mathrm{g} / \mathrm{g}$ for $\mathrm{Mn}, \mathrm{Fe}, \mathrm{Cu}$, and $\mathrm{Zn}$ (Jorhem et al., 1984). In Egypt, Abou-Arab (2001) reported that the levels of $\mathrm{Fe}, \mathrm{Zn}, \mathrm{Cu}, \mathrm{Mn}, \mathrm{Cd}$ and $\mathrm{Pb}$ ranged from 82.6 to $116.4,19.8$ to $26.2,38.4$ to $86.4,1.9$ to $4.8,0.082$ to 0.112 , and 0.08 to $0.11 \mu \mathrm{g} / \mathrm{g}$ wt. weight in liver samples from bovine, buffalo, elk, sheep and goat, respectively. There was no more available data in the literature relating to the study of trace elements in chicken liver or chicken liver paste (foie gras).

The processing of chicken liver paste (foie gras) from raw chicken liver produced different compositions of the product due to a loss of moisture, fat releasing and butter addition as fat source. Chicken liver paste contained $27.8 \%$ moisture, $10.1 \%$ protein, $58.2 \%$ fat, and $0.8 \%$ ash. Mineral contents were 68.90, 40.50, 1.60, 1.1, 0.08, $0.22,0.04$ and $0.04 \mu \mathrm{g} / \mathrm{g}$ of $\mathrm{Fe}, \mathrm{Zn}, \mathrm{Cu}, \mathrm{Mn}, \mathrm{Cd}, \mathrm{Pb}$, $\mathrm{Ni}$, and $\mathrm{Cr}$, respectively.

Fat release during cooking depends on temperature and length of the heating process (Blum, 1997). It increases with the liver weight and is related to its composition. Liver paste (foie gras) from geese lost less fat during cooking and there was only a small influence of the liver weight; those of mule ducks lost more, the loss increasing quickly with the liver weight; those of muscovy ducks lost a maximum value (56\%) independently of the liver weight (Blum, 1997). On the other hand, (Salichon et al., 1994) reported that the lipid contents were significantly $(P<0.001)$ higher in duck foie gras $(62.6 \%$ in muscovy and $60.5 \%$ in mule ducks vs $54.6 \%$ in geese), while water, protein and ash contents were lower, which were recorded at 27.4$37.7,6.4-8.3$, and $0.5-0.7 \%$ for geese , mule ducks and muscovy, respectively. The same constitute of foie gras from duck liver as from chicken liver was applied to the sensory analysis (Table 1).

Lipid oxidation, microbial spoilage and associated changes are major causes of quality deterioration of meat during storage. Problems

Table 1

Proximate mineral composition of raw chicken liver, foi gras from chicken liver and fois gras from duck liver

\begin{tabular}{cccc}
\hline Components & $\begin{array}{c}\text { Raw chicken } \\
\text { liver }\end{array}$ & $\begin{array}{c}\text { Foie gras from } \\
\text { Chicken liver }\end{array}$ & $\begin{array}{c}\text { Foie gras from } \\
\text { Duck liver }\end{array}$ \\
\hline Proximate \% (wet weight) & & & 28.60 \\
Moisture & 66.80 & 27.80 & 9.40 \\
Protein & 24.60 & 10.10 & 56.80 \\
Fat & 6.00 & 58.20 & 0.90 \\
Ash & 1.40 & 0.80 & 79.60 \\
Minerals ( $\mu$ g/g wet weight) & & & 51.10 \\
Fe & 83.65 & 68.90 & 3.30 \\
Zn & 50.75 & 40.50 & 3.40 \\
$\mathrm{Cu}$ & 5.29 & 1.60 & 0.26 \\
$\mathrm{Cd}$ & 1.15 & 1.10 & 0.80 \\
$\mathrm{~Pb}$ & 0.154 & 0.08 & 0.12 \\
$\mathrm{Ni}$ & 0.683 & 0.22 & 0.08 \\
$\mathrm{Cr}$ & 0.317 & 0.04 & 0.04 \\
\hline
\end{tabular}


associated with lipid oxidation are of importance as they relate to flavor deterioration and loss of nutritional value, thereby affecting the acceptability of meat after storage (Gray and Monahan, 1992). Chemical, microbiological, and sensory evaluation of chicken liver paste (foie gras) manufactured from chicken liver and preserved with 1000 ppm of either benzoic acid or sorbic acid and a mixture of 500 ppm of both benzoic acid and sorbic acid as well as pasteurized at $85^{\circ} \mathrm{C}$ or unpasteurized were studied during the storage periods for $0,3,6$, and 9 days at $4{ }^{\circ} \mathrm{C}$ (Tables, 2-8).

Table (2) clearly shows that storage periods had significantly $(P<0.05)$ increased thiobarbituric acid (TBA) in pasteurized or unpasteurized samples with or without BA and SA. However, samples pasteurized at $85{ }^{\circ} \mathrm{C}$ had significantly $(P<0.05)$ lower TBA compared to the unpasteurized control treatment at 9 storage days . Moreover, the addition of $1000 \mathrm{ppm}$ of BA or SA to unpasteurized samples at 9 storage days or BA plus SA mixture at 6 or 9 storage days had significantly $(P<0.05)$ lower levels of TBA compared to control treatments. Also, the addition of 1000 ppm of SA or BA plus SA mixture to pasteurized samples had significantly $(P<0.05)$ decreased TBA at 9 storage days compared to the control treatment. Similar results were obtained by Abu-Salem and Khalaf, (1988); Estevez and Cava, (2004) who reported that there were increases in TBA by increasing the storage periods of chicken meat products and pork. Also, Gray and Monahan, (1992) recommended the mixing of ground buffalo meat with 600 ppm sodium ascorbate plus $5 \mathrm{ppm} \alpha$-tocopherol acetate for decreasing TBA up to six days of refrigerated storage. Presumably, adding BA + SA mixture to chicken liver paste (foie gras) and pasteurizing the product at $85{ }^{\circ} \mathrm{C}$ could be recommended for lowering TBA values and hence for inhibiting lipid oxidation as well as preventing rancidity to a period of up to nine days of refrigerated storage $\left(4^{\circ} \mathrm{C}\right)$.

The data in Table 3 shows that total volatile nitrogen (TVN) increased significantly $(P<0.05)$ in different treatments as storage periods increased. On the contrary, TVN decreased significantly $(P<0.05)$ at 6 or 9 storage days in different samples pasteurized at $85{ }^{\circ} \mathrm{C}$ compared with unpasteurized treatments. Moreover, the addition of $1000 \mathrm{ppm}$ of $\mathrm{BA}, \mathrm{SA}$ or BA plus SA mixture to unpasteurized or pasteurized samples at 3,6 and 9 storage days produced a significant $(P<0.05)$ decrease in TVN compared to its control treatments. Also, the addition of the BA plus SA mixture to different treatments at 3, 6 and 9 storage days resulted in a significant $(\mathrm{P}<0.05)$ decrease in TVN as compared to the addition of BA or SA alone. These findings are in agreement with Abu-Salem and Khalaf, (1988) who reported that TVN increases with an increasing in storage time for chicken meat products. Such results agree with those reported by (Pearson et al., 1976); (Demyer and Vandekevchkove, 1979). TVN is an index for the degree of putrification and breakdown of proteinaceous constituents (El-Saaid Basuni, 1993). (Abu-Salem and Khallaf, 1988) reported an increase in TVN during frozen storage due to the breakdown of proteins. Such protein decomposition could be due to the microbial activity. It could also be noticed that protein hydrolysis and microbial breakdown were responsible for this increase. These results would suggest that the addition of BA plus SA and pasteurizing the product at $85^{\circ} \mathrm{C}$ is affective for decreasing TVN in products. A

Table 2

Change in TBA values (mg malonaldehyde/kg) of chicken liver paste (foie gras) preserved by benzoic and / or sorbic acid and pasteurized at $85^{\circ} \mathrm{C}$ or unpasteurized during storage period (Mean \pm SD)

\begin{tabular}{|c|c|c|c|c|c|c|c|c|}
\hline \multirow{3}{*}{$\begin{array}{l}\text { Storage } \\
\text { period } \\
\text { (day) }\end{array}$} & \multicolumn{8}{|c|}{ Treatments } \\
\hline & \multicolumn{4}{|c|}{ Unpasteurized } & \multicolumn{4}{|c|}{ Pasteurized } \\
\hline & Control & $\begin{array}{c}\text { BA } \\
1000 \text { ppm }\end{array}$ & $\begin{array}{c}\text { SA } \\
1000 \text { ppm }\end{array}$ & $\begin{array}{c}\text { BA + SA } \\
500 \text { ppm } \\
\text { of both }\end{array}$ & Control & $\begin{array}{c}\text { BA } \\
1000 \text { ppm }\end{array}$ & $\begin{array}{c}\text { SA } \\
1000 \text { ppm }\end{array}$ & $\begin{array}{c}S A+B A \\
500 \text { ppm } \\
\text { of both }\end{array}$ \\
\hline \multirow{3}{*}{0} & $0.22^{k}$ & $0.22^{k}$ & $0.22^{k}$ & $0.22^{k}$ & $0.22^{k}$ & $0.22^{k}$ & $0.22^{k}$ & $0.22^{k}$ \\
\hline & \pm & \pm & \pm & \pm & \pm & \pm & \pm & \pm \\
\hline & 0.01 & 0.01 & 0.01 & 0.01 & 0.01 & 0.01 & 0.01 & 0.01 \\
\hline \multirow{3}{*}{3} & $0.45^{\prime}$ & $0.41^{\mathrm{ij}}$ & $0.40^{\mathrm{ij}}$ & $0.38^{j}$ & $0.42^{i j}$ & $0.40^{\mathrm{ij}}$ & $0.38^{j}$ & $0.36^{j}$ \\
\hline & \pm & \pm & \pm & \pm & \pm & \pm & \pm & \pm \\
\hline & 0.02 & 0.02 & 0.03 & 0.01 & 0.01 & 0.02 & 0.03 & 0.02 \\
\hline \multirow{3}{*}{6} & $0.68^{e f}$ & $0.64^{\text {efgh }}$ & $0.64^{\text {efgh }}$ & $0.61^{g h}$ & $0.65^{\text {efg }}$ & $0.62^{f g h}$ & $0.61^{\text {gh }}$ & $0.58^{h}$ \\
\hline & \pm & \pm & \pm & \pm & \pm & \pm & \pm & \pm \\
\hline & 0.03 & 0.02 & 0.01 & 0.04 & 0.03 & 0.03 & 0.01 & 0.01 \\
\hline \multirow{3}{*}{9} & $0.96^{a}$ & $0.80^{\mathrm{bc}}$ & $0.78^{b c}$ & $0.75^{\mathrm{cd}}$ & $0.82^{b}$ & $0.77^{b c}$ & $0.75^{\mathrm{cd}}$ & $0.70^{\text {de }}$ \\
\hline & \pm & \pm & \pm & \pm & \pm & \pm & \pm & \pm \\
\hline & 0.01 & 0.01 & 0.03 & 0.03 & 0.02 & 0.02 & 0.02 & 0.02 \\
\hline
\end{tabular}

$\mathrm{a}, \mathrm{b}, \mathrm{c}$ Means within in each column having different superscript are significantly different $(P<0.05)$. Values are means of three replicates. BA: Benzoic acid. SA: Sorbic acid. BA + SA: Benzoic acid plus Sorbic acid. 
Table 3

Changes in TVN (mg/100g)) of chicken liver paste (foie gras) preserved by benzoic and / or sorbic acid and pasteurized at $85^{\circ} \mathrm{C}$ or unpasteurized during storage periods (Mean \pm SD)

\begin{tabular}{|c|c|c|c|c|c|c|c|c|}
\hline \multirow{3}{*}{$\begin{array}{c}\text { Storage } \\
\text { period } \\
\text { (day) }\end{array}$} & \multicolumn{8}{|c|}{ Treatments } \\
\hline & \multicolumn{4}{|c|}{ Unpasteurized } & \multicolumn{4}{|c|}{ Pasteurized } \\
\hline & Control & $\begin{array}{c}\text { BA } \\
1000 \text { ppm }\end{array}$ & $\begin{array}{c}\text { SA } \\
1000 \text { ppm }\end{array}$ & $\begin{array}{c}\text { BA+SA } \\
500 \text { ppm } \\
\text { of both }\end{array}$ & Control & $\begin{array}{c}\text { BA } \\
1000 \text { ppm }\end{array}$ & $\begin{array}{c}\text { SA } \\
1000 \text { ppm }\end{array}$ & $\begin{array}{c}\text { SA+BA } \\
500 \text { ppm } \\
\text { of both }\end{array}$ \\
\hline 0 & $\begin{array}{c}3.20^{r} \\
\pm \\
0.01\end{array}$ & $\begin{array}{c}3.20^{r} \\
\pm \\
0.01\end{array}$ & $\begin{array}{c}3.20^{r} \\
\pm \\
0.01\end{array}$ & $\begin{array}{c}3.20^{r} \\
\pm \\
0.01\end{array}$ & $\begin{array}{c}3.20^{r} \\
\pm \\
0.01\end{array}$ & $\begin{array}{c}3.20^{r} \\
\pm \\
0.01\end{array}$ & $\begin{array}{c}3.20^{r} \\
\pm \\
0.01\end{array}$ & $\begin{array}{c}3.20^{r} \\
\pm \\
0.01\end{array}$ \\
\hline 3 & $\begin{array}{c}4.85^{1} \\
\pm \\
0.01\end{array}$ & $\begin{array}{c}4.65^{\mathrm{mn}} \\
\pm \\
0.01\end{array}$ & $\begin{array}{c}4.63^{\mathrm{mn}} \\
\pm \\
0.03\end{array}$ & $\begin{array}{c}4.50^{\circ p} \\
\pm \\
0.03\end{array}$ & $\begin{array}{c}4.75^{\mathrm{lm}} \\
\pm \\
0.01\end{array}$ & $\begin{array}{c}4.60^{\text {on }} \\
\pm \\
0.03\end{array}$ & $\begin{array}{c}4.41^{p} \\
\pm \\
0.02\end{array}$ & $\begin{array}{c}4.03^{q} \\
\pm \\
0.02\end{array}$ \\
\hline 6 & $\begin{array}{c}6.85^{\dagger} \\
\pm \\
0.02\end{array}$ & $\begin{array}{c}6.42^{g} \\
\pm \\
0.02\end{array}$ & $\begin{array}{c}6.40^{9} \\
\pm \\
0.02\end{array}$ & $\begin{array}{c}6.01^{\prime} \\
\pm \\
0.01\end{array}$ & $\begin{array}{c}6.42^{g} \\
\pm \\
0.03\end{array}$ & $\begin{array}{c}6.02 \\
\pm \\
0.03\end{array}$ & $\begin{array}{c}5.52^{j} \\
\pm \\
0.02\end{array}$ & $\begin{array}{c}5.12^{k} \\
\pm \\
0.02\end{array}$ \\
\hline 9 & $\begin{array}{c}8.25^{a} \\
\pm \\
0.03\end{array}$ & $\begin{array}{c}7.99^{b} \\
\pm \\
0.03\end{array}$ & $\begin{array}{c}7.60^{c} \\
\pm \\
0.03\end{array}$ & $\begin{array}{c}7.02^{d} \\
\pm \\
0.02\end{array}$ & $\begin{array}{c}8.02^{b} \\
\pm \\
0.01\end{array}$ & $\begin{array}{c}7.03^{e} \\
\pm \\
0.03\end{array}$ & $\begin{array}{c}6.85^{\dagger} \\
\pm \\
0.01\end{array}$ & $\begin{array}{c}6.18^{h} \\
\pm \\
0.02\end{array}$ \\
\hline
\end{tabular}

$\overline{a, b, c}$ Means within in each column having different superscript are significantly different $(P<0.05)$. Values are means of three replicates. BA: Benzoic acid. SA: Sorbic acid. BA + SA: Benzoic acid plus Sorbic acid.

Table 4

Changes in PV (mg/kg extract fat) of chicken liver paste (foie gras) preserved by benzoic and /or sorbic acid and pasteurized at $85{ }^{\circ} \mathrm{C}$ or unpasteurized during storage periods (Mean \pm SD)

\begin{tabular}{|c|c|c|c|c|c|c|c|c|}
\hline \multirow{3}{*}{$\begin{array}{c}\text { Storage } \\
\text { period } \\
\text { (day) }\end{array}$} & \multicolumn{8}{|c|}{ Treatments } \\
\hline & \multicolumn{4}{|c|}{ Unpasteurized } & \multicolumn{4}{|c|}{ Pasteurized } \\
\hline & Control & $\begin{array}{c}\text { BA } \\
1000 \mathrm{ppm}\end{array}$ & $\begin{array}{c}\text { SA } \\
1000 \text { ppm }\end{array}$ & $\begin{array}{c}\text { BA+SA } \\
500 \text { ppm } \\
\text { of both }\end{array}$ & Control & $\begin{array}{c}\text { BA } \\
1000 \text { ppm }\end{array}$ & $\begin{array}{c}\text { SA } \\
1000 \text { ppm }\end{array}$ & $\begin{array}{c}\text { SA+BA } \\
500 \text { ppm } \\
\text { of both }\end{array}$ \\
\hline 0 & $\begin{array}{c}1.50^{t} \\
\pm \\
0.00\end{array}$ & $\begin{array}{c}1.50^{t} \\
\pm \\
0.00\end{array}$ & $\begin{array}{c}1.50^{t} \\
\pm \\
0.00\end{array}$ & $\begin{array}{c}1.50^{t} \\
\pm \\
0.00\end{array}$ & $\begin{array}{c}1.50^{t} \\
\pm \\
0.00\end{array}$ & $\begin{array}{c}1.50^{t} \\
\pm \\
0.00\end{array}$ & $\begin{array}{c}1.50^{t} \\
\pm \\
0.00\end{array}$ & $\begin{array}{c}1.50^{t} \\
\pm \\
0.00\end{array}$ \\
\hline 3 & $\begin{array}{c}2.90^{n} \\
\pm \\
0.02\end{array}$ & $\begin{array}{c}4.40^{p} \\
\pm \\
0.02\end{array}$ & $\begin{array}{c}2.35^{p} \\
\pm \\
0.03\end{array}$ & $\begin{array}{c}2.25^{q} \\
\pm \\
0.02\end{array}$ & $\begin{array}{c}2.82^{\circ} \\
\pm \\
0.02\end{array}$ & $\begin{array}{c}2.25^{q} \\
\pm \\
0.02\end{array}$ & $\begin{array}{c}2.18^{r} \\
\pm \\
0.03\end{array}$ & $\begin{array}{c}2.01^{s} \\
\pm \\
0.01\end{array}$ \\
\hline 6 & $\begin{array}{c}4.25^{g} \\
\pm \\
0.02\end{array}$ & $\begin{array}{c}4.02^{i} \\
\pm \\
0.02\end{array}$ & $\begin{array}{c}3.95^{j} \\
\pm \\
0.02\end{array}$ & $\begin{array}{c}3.75^{1} \\
\pm \\
0.01\end{array}$ & $\begin{array}{c}4.02 \\
\pm \\
0.02\end{array}$ & $\begin{array}{c}3.85^{\mathrm{k}} \\
\pm \\
0.01\end{array}$ & $\begin{array}{c}3.70 \\
\pm \\
0.03\end{array}$ & $\begin{array}{c}3.55^{\mathrm{m}} \\
\pm \\
0.03\end{array}$ \\
\hline 9 & $\begin{array}{c}5.60^{\mathrm{a}} \\
\pm \\
0.01\end{array}$ & $\begin{array}{c}5.00^{c} \\
\pm \\
0.01\end{array}$ & $\begin{array}{c}4.85^{\mathrm{d}} \\
\pm \\
0.02\end{array}$ & $\begin{array}{c}4.50^{f} \\
\pm \\
0.02\end{array}$ & $\begin{array}{c}5.25^{\mathrm{b}} \\
\pm \\
0.02\end{array}$ & $\begin{array}{c}4.75^{\mathrm{e}} \\
\pm \\
0.02\end{array}$ & $\begin{array}{c}4.55^{f} \\
\pm \\
0.02\end{array}$ & $\begin{array}{l}4.18^{h} \\
\pm \\
0.03\end{array}$ \\
\hline
\end{tabular}

$\overline{a, b, c}$ Means within a row having different superscript are significantly different $(\mathrm{P}<0.05)$. Values are means of three replicates. BA: Benzoic acid. SA: Sorbic acid. BA+SA: Benzoic acid plus Sorbic acid.

significantly $(P<0.05)$ increased peroxide value (PV) was produced due to the storage periods at $4{ }^{\circ} \mathrm{C}$ with treated or untreated samples (Table 4). In contrast, PV decreased significantly $(P<0.05)$ at 3,6 or 9 storage days in different pasteurized samples compared with unpasteurized treatments. Also, adding 1000 ppm of BA, SA or the BA plus SA mixture to unpasteurized or pasteurized samples at 3, 6 and 9 storage days produced a significant $(P<0.05)$ decrease in $P V$ compared to its control treatments. A significantly higher decrease $(P<0.05)$ was detected due to BA plus SA mixture compared with either BA or SA alone. Generally, the decrease in PV was in the following order: BA plus SA mixture followed by SA and then BA or the significant reduction of PV was more profound due to adding 
the BA plus SA mixture to chicken liver paste. It could be recommended that the mixture of $B A+S A$ is most affective to decrease PV, especially with pasteurization at $85^{\circ} \mathrm{C}$.

The data in Table (5) shows that a significant $(P<0.05)$ increase in free fatty acid (FFA) was detected due to the storage period at $4{ }^{\circ} \mathrm{C}$ regardless of the different treatments. In contrast,
FFA decreased significantly $(P<0.05)$ at 6 or 9 storage days in untreated samples and at 9 days in treated, pasteurized samples compared with unpasteurized treatments. Also, adding 1000 ppm of BA, SA or the BA plus SA mixture to unpasteurized or pasteurized samples at 3,6 and 9 storage days significantly $(P<0.05)$ decreased FFA compared to its control treatments. Generally,

Table 5

Changes in free fatty acid (FFA) as oleic acid of chicken liver paste (foie gras) preserved by benzoic and / or sorbic acid and pasteurized at $85^{\circ} \mathrm{C}$ or unpasteurized during storage period (Mean \pm SD)

\begin{tabular}{|c|c|c|c|c|c|c|c|c|}
\hline \multirow{3}{*}{$\begin{array}{c}\text { Storage } \\
\text { period } \\
\text { (day) }\end{array}$} & \multicolumn{8}{|c|}{ Treatments } \\
\hline & \multicolumn{4}{|c|}{ Unpasteurized } & \multicolumn{4}{|c|}{ Pasteurized } \\
\hline & Control & $\begin{array}{c}\text { BA } \\
1000 \text { ppm }\end{array}$ & $\begin{array}{c}\text { SA } \\
1000 \text { ppm }\end{array}$ & $\begin{array}{c}\text { BA+SA } \\
500 \text { ppm } \\
\text { of both }\end{array}$ & Control & $\begin{array}{c}\text { BA } \\
1000 \text { ppm }\end{array}$ & $\begin{array}{c}\text { SA } \\
1000 \text { ppm }\end{array}$ & $\begin{array}{c}\text { SA+BA } \\
500 \text { ppm } \\
\text { of both }\end{array}$ \\
\hline 0 & $\begin{array}{c}0.25^{\mathrm{b}} \\
\pm \\
0.00\end{array}$ & $\begin{array}{c}0.25^{b} \\
\pm \\
0.00\end{array}$ & $\begin{array}{c}0.25^{b} \\
\pm \\
0.00\end{array}$ & $\begin{array}{c}0.25^{b} \\
\pm \\
0.00\end{array}$ & $\begin{array}{c}0.25^{b} \\
\pm \\
0.00\end{array}$ & $\begin{array}{c}0.25^{b} \\
\pm \\
0.00\end{array}$ & $\begin{array}{c}0.25^{b} \\
\pm \\
0.00\end{array}$ & $\begin{array}{c}0.25^{b} \\
\pm \\
0.00\end{array}$ \\
\hline 3 & $\begin{array}{c}0.50 \\
\pm \\
0.02\end{array}$ & $\begin{array}{c}0.45^{\mathrm{Im}} \\
\pm \\
0.02\end{array}$ & $\begin{array}{c}0.42^{\mathrm{mn}} \\
\pm \\
0.02\end{array}$ & $\begin{array}{c}0.40^{\mathrm{mno}} \\
\pm \\
0.02\end{array}$ & $\begin{array}{c}0.48^{1} \\
\pm \\
0.02\end{array}$ & $\begin{array}{c}0.42^{\mathrm{mn}} \\
\pm \\
0.02\end{array}$ & $\begin{array}{c}0.38^{\text {no }} \\
\pm \\
0.02\end{array}$ & $\begin{array}{c}0.35^{\circ} \\
\pm \\
0.01\end{array}$ \\
\hline 6 & $\begin{array}{c}0.98^{f} \\
\pm \\
0.01\end{array}$ & $\begin{array}{c}0.85^{\mathrm{h}} \\
\pm \\
0.01\end{array}$ & $\begin{array}{c}0.80^{\mathrm{hij}} \\
\pm \\
0.01\end{array}$ & $\begin{array}{c}0.76^{i j} \\
\pm \\
0.02\end{array}$ & $\begin{array}{c}0.90^{9} \\
\pm \\
0.03\end{array}$ & $\begin{array}{c}0.81^{\text {hi }} \\
\pm \\
0.01\end{array}$ & $\begin{array}{c}0.75^{\mathrm{j}} \\
\pm \\
0.01\end{array}$ & $\begin{array}{c}0.68^{\mathrm{k}} \\
\pm \\
0.03\end{array}$ \\
\hline 9 & $\begin{array}{c}1.35^{\mathrm{a}} \\
\pm \\
0.02\end{array}$ & $\begin{array}{c}1.26^{b} \\
\pm \\
0.03\end{array}$ & $\begin{array}{c}1.24^{\mathrm{bc}} \\
\pm \\
0.02\end{array}$ & $\begin{array}{c}1.18^{d} \\
\pm \\
0.02\end{array}$ & $\begin{array}{c}1.25^{\mathrm{bc}} \\
\pm \\
0.02\end{array}$ & $\begin{array}{c}1.20^{\mathrm{cd}} \\
\pm \\
0.02\end{array}$ & $\begin{array}{c}1.18^{d} \\
\pm \\
0.02\end{array}$ & $\begin{array}{c}1.12^{\mathrm{e}} \\
\pm \\
0.02\end{array}$ \\
\hline
\end{tabular}

$\overline{a, b, c}$ Means within a row having different superscript are significantly different $(\mathrm{P}<0.05)$. Values are means of three replicates. BA: Benzoic acid. SA: Sorbic acid. BA + SA: Benzoic acid plus Sorbic acid.

Table 6

Changes in ammonia content $(\mathrm{mg} / \mathbf{1 0 0 \mathrm { g }})$ of chicken liver paste (foie gras) preserved by benzoic and / or sorbic acid and pasteurized at $85^{\circ} \mathrm{C}$ or unpasteurized during storage periods (Mean \pm SD)

\begin{tabular}{|c|c|c|c|c|c|c|c|c|}
\hline \multirow{3}{*}{$\begin{array}{c}\text { Storage } \\
\text { period } \\
\text { (day) }\end{array}$} & \multicolumn{8}{|c|}{ Treatments } \\
\hline & \multicolumn{4}{|c|}{ Unpasteurized } & \multicolumn{4}{|c|}{ Pasteurized } \\
\hline & Control & $\begin{array}{c}\text { BA } \\
1000 \text { ppm }\end{array}$ & $\begin{array}{c}\text { SA } \\
1000 \text { ppm }\end{array}$ & $\begin{array}{c}\text { BA+SA } \\
500 \text { ppm } \\
\text { of both }\end{array}$ & Control & $\begin{array}{c}\text { BA } \\
1000 \mathrm{ppm}\end{array}$ & $\begin{array}{c}\text { SA } \\
1000 \text { ppm }\end{array}$ & $\begin{array}{c}\text { SA+BA } \\
500 \text { ppm } \\
\text { of both }\end{array}$ \\
\hline 0 & $\begin{array}{c}1.82^{\mathrm{m}} \\
\pm \\
0.00\end{array}$ & $\begin{array}{c}1.82^{\mathrm{m}} \\
\pm \\
0.00\end{array}$ & $\begin{array}{c}1.82^{\mathrm{m}} \\
\pm \\
0.00\end{array}$ & $\begin{array}{c}1.82^{m} \\
\pm \\
0.00\end{array}$ & $\begin{array}{c}1.82^{\mathrm{m}} \\
\pm \\
0.00\end{array}$ & $\begin{array}{c}1.82^{m} \\
\pm \\
0.00\end{array}$ & $\begin{array}{c}1.82^{m} \\
\pm \\
0.00\end{array}$ & $\begin{array}{c}1.82^{\mathrm{m}} \\
\pm \\
0.00\end{array}$ \\
\hline 3 & $\begin{array}{c}1.99 \\
\pm \\
0.02\end{array}$ & $\begin{array}{c}1.81^{\mathrm{m}} \\
\pm \\
0.01\end{array}$ & $\begin{array}{c}1.80^{\mathrm{mn}} \\
\pm \\
0.02\end{array}$ & $\begin{array}{c}1.75^{\text {no }} \\
\pm \\
0.01\end{array}$ & $\begin{array}{c}1.85^{\mathrm{m}} \\
\pm \\
0.02\end{array}$ & $\begin{array}{c}1.75^{\text {no }} \\
\pm \\
0.02\end{array}$ & $\begin{array}{c}1.70^{\circ} \\
\pm \\
0.03\end{array}$ & $\begin{array}{c}1.61^{p} \\
\pm \\
0.02\end{array}$ \\
\hline 6 & $\begin{array}{c}2.83^{g} \\
\pm \\
0.03\end{array}$ & $\begin{array}{c}2.75^{\mathrm{hi}} \\
\pm \\
0.01\end{array}$ & $\begin{array}{c}2.70^{i} \\
\pm \\
0.02\end{array}$ & $\begin{array}{c}2.75^{\mathrm{hi}} \\
\pm \\
0.03\end{array}$ & $\begin{array}{c}2.80^{g h} \\
\pm \\
0.01\end{array}$ & $\begin{array}{c}2.60^{j} \\
\pm \\
0.03\end{array}$ & $\begin{array}{c}2.58^{j} \\
\pm \\
0.03\end{array}$ & $\begin{array}{c}2.42^{k} \\
\pm \\
0.01\end{array}$ \\
\hline 9 & $\begin{array}{c}4.20^{a} \\
\pm \\
0.02\end{array}$ & $\begin{array}{c}4.05^{\mathrm{b}} \\
\pm \\
0.02\end{array}$ & $\begin{array}{c}3.95^{c} \\
\pm \\
0.02\end{array}$ & $\begin{array}{c}3.90^{c} \\
\pm \\
0.01\end{array}$ & $\begin{array}{c}4.09^{b} \\
\pm \\
0.01\end{array}$ & $\begin{array}{c}3.80^{d} \\
\pm \\
0.03\end{array}$ & $\begin{array}{c}3.70^{e} \\
\pm \\
0.03\end{array}$ & $\begin{array}{c}3.45^{f} \\
\pm \\
0.02\end{array}$ \\
\hline
\end{tabular}

a, b, c Means within a row having different superscript are significantly different $(P<0.05)$. Values are means of three replicates. BA: Benzoic acid.SA: Sorbic acid.BA + SA: Benzoic acid plus Sorbic acid. 
Table 7

Changes in saponification value of chicken liver paste (foie gras) preserved by benzoic and / or sorbic acid and pasteurized at $85^{\circ} \mathrm{C}$ or unpasteurized during storage periods (Mean \pm SD)

\begin{tabular}{|c|c|c|c|c|c|c|c|c|}
\hline \multirow{3}{*}{$\begin{array}{c}\text { Storage } \\
\text { period } \\
\text { (day) }\end{array}$} & \multicolumn{8}{|c|}{ Treatments } \\
\hline & \multicolumn{4}{|c|}{ Unpasteurized } & \multicolumn{4}{|c|}{ Pasteurized } \\
\hline & Control & $\begin{array}{c}\text { BA } \\
1000 \text { ppm }\end{array}$ & $\begin{array}{c}\text { SA } \\
1000 \text { ppm }\end{array}$ & $\begin{array}{c}\text { BA+SA } \\
500 \text { ppm } \\
\text { of both }\end{array}$ & Control & $\begin{array}{c}\text { BA } \\
1000 \text { ppm }\end{array}$ & $\begin{array}{c}\text { SA } \\
1000 \text { ppm }\end{array}$ & $\begin{array}{c}\text { SA+BA } \\
500 \text { ppm } \\
\text { of both }\end{array}$ \\
\hline 0 & $\begin{array}{c}150.30^{v} \\
\pm \\
0.01\end{array}$ & $\begin{array}{c}150.30^{v} \\
\pm \\
0.01\end{array}$ & $\begin{array}{c}150.30^{v} \\
\pm \\
0.01\end{array}$ & $\begin{array}{c}150.30^{v} \\
\pm \\
0.01\end{array}$ & $\begin{array}{c}150.30^{v} \\
\pm \\
0.01\end{array}$ & $\begin{array}{c}150.30^{v} \\
\pm \\
0.01\end{array}$ & $\begin{array}{c}150.30^{v} \\
\pm \\
0.01\end{array}$ & $\begin{array}{c}150.30^{v} \\
\pm \\
0.01\end{array}$ \\
\hline 3 & $\begin{array}{c}152.80^{p} \\
\pm \\
0.03\end{array}$ & $\begin{array}{c}151.75^{\mathrm{q}} \\
\pm \\
0.03\end{array}$ & $\begin{array}{c}151.61^{r} \\
\pm \\
0.01\end{array}$ & $\begin{array}{c}151.51^{\mathrm{s}} \\
\pm \\
0.02\end{array}$ & $\begin{array}{c}152.75^{p} \\
\pm \\
0.03\end{array}$ & $\begin{array}{c}151.60^{r} \\
\pm \\
0.04\end{array}$ & $\begin{array}{c}151.21^{\mathrm{t}} \\
\pm \\
0.01\end{array}$ & $\begin{array}{c}150.85^{\mathrm{u}} \\
\pm \\
0.03\end{array}$ \\
\hline 6 & $\begin{array}{c}158.30^{d} \\
\pm \\
0.03\end{array}$ & $\begin{array}{c}157.02^{\mathrm{i}} \\
\pm \\
0.02\end{array}$ & $\begin{array}{c}156.80^{\mathrm{i}} \\
\pm \\
0.02\end{array}$ & $\begin{array}{c}154.90^{n} \\
\pm \\
0.02\end{array}$ & $\begin{array}{c}158.00^{f} \\
\pm \\
0.02\end{array}$ & $\begin{array}{c}155.92 \\
\pm \\
0.02\end{array}$ & $\begin{array}{c}155.93 \\
\pm \\
0.03\end{array}$ & $\begin{array}{c}154.00^{\circ} \\
\pm \\
0.04\end{array}$ \\
\hline 9 & $\begin{array}{c}160.40^{\mathrm{a}} \\
\pm \\
0.02\end{array}$ & $\begin{array}{c}159.30^{c} \\
\pm \\
0.03\end{array}$ & $\begin{array}{c}158.18^{\mathrm{e}} \\
\pm \\
0.01\end{array}$ & $\begin{array}{c}156.20^{k} \\
\pm \\
0.02\end{array}$ & $\begin{array}{c}159.85^{\mathrm{b}} \\
\pm \\
0.01\end{array}$ & $\begin{array}{c}157.40^{\mathrm{g}} \\
\pm \\
0.03\end{array}$ & $\begin{array}{c}157.30^{h} \\
\pm \\
0.03\end{array}$ & $\begin{array}{c}155.30^{\mathrm{m}} \\
\pm \\
0.03\end{array}$ \\
\hline
\end{tabular}

a, b, c Means within a row having different superscript are significantly different $(P<0.05)$. Values are means of three replicates. BA: Benzoic acid. SA: Sorbic acid. BA + SA: Benzoic acid plus Sorbic acid.

Table 8

Microbiological analysis of (c.f.u/g) of chicken liver paste (foie gras) preserved by benzoic and / or sorbic acid and pasteurized at $85^{\circ} \mathrm{C}$ or unpasteurized after 9 days of storage period

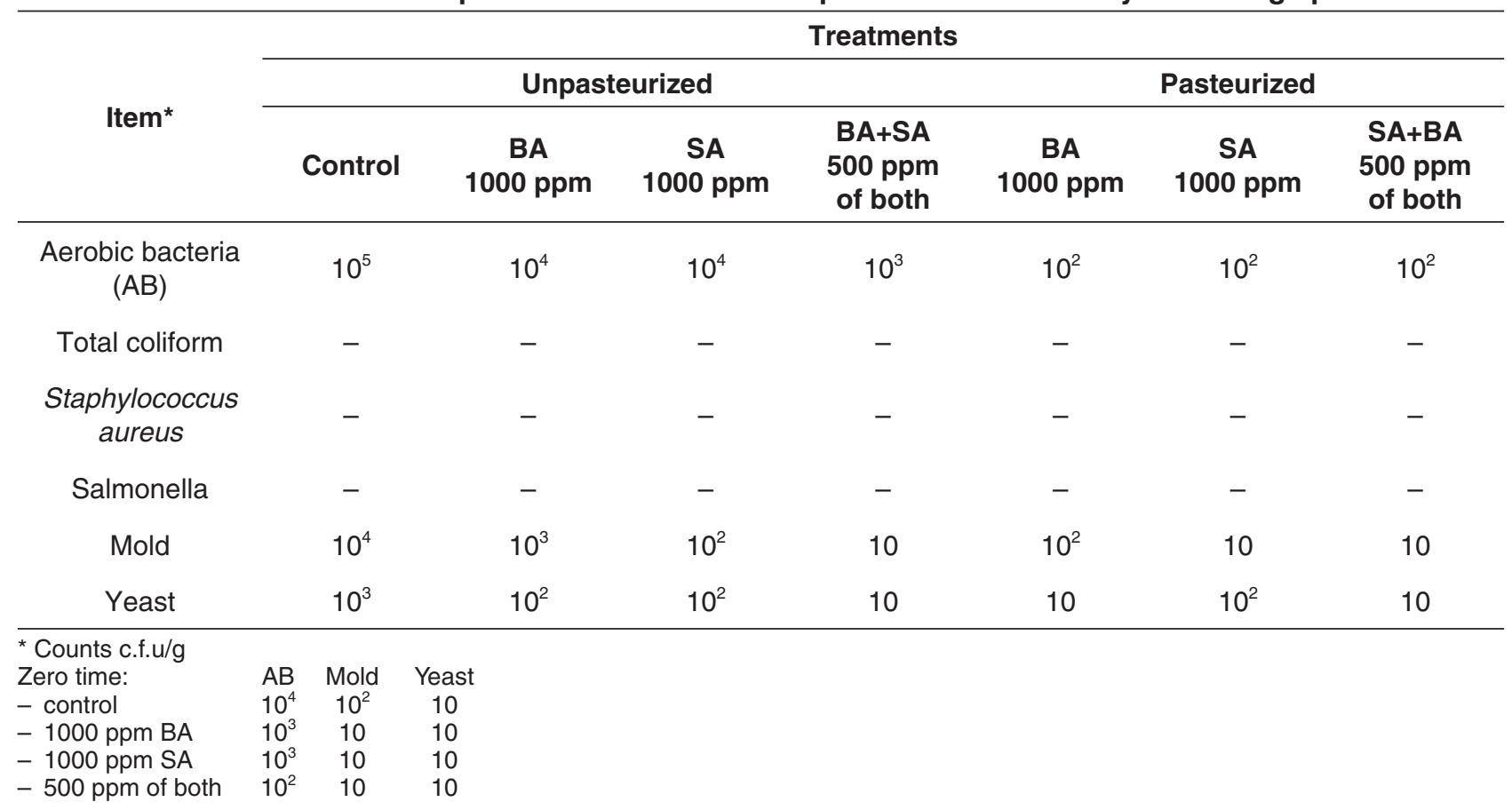

a significant $(P<0.05)$ decrease wasdetected due to the $\mathrm{BA}+\mathrm{SA}$ mixture at 9 storage days in unpasteurized or at 6 or 9 storage days in pasteurized treatments compared with either BA or $\mathrm{SA}$ alone. The decrease in FFA was in the following order: BA plus SA mixture followed by SA and then $\mathrm{BA}$ or the significant reduction in FFA was more profound due to adding the BA plus SA mixture to chicken liver paste. These finding are in agreement with (Abu-Salem and Khalaf, 1988) who reported an increase in FFA of chicken meat products by increasing storage time. Also, (Fishwish,1968) found that FFA increased during storage at 0 , $-3,-10$ and $-20{ }^{\circ} \mathrm{C}$ indicating lipolytic changes. This increase could be due to fat hydrolysis and the enzymatic oxidation of fatty acids by 
microorganisms, as stated by (Branen, 1979). A mixture of BA plus SA could be recommended to decrease FFA especially with the pasteurization at $85^{\circ} \mathrm{C}$.

The data in (Table 6) show significant $(P<0.05)$ increases in ammonia contents as a result of storage periods at $4{ }^{\circ} \mathrm{C}$ in all different treatments. However, the stored, pasteurized product had significantly $(P<0.05)$ lower ammonia contents at 3,6 or 9 storage days compared with unpasteurized treatments. Moreover, storage products, pasteurized or unpasteurized, mixed with 1000 ppm of BA, SA or BA plus $S A$ mixture showed significant $(P<0.05)$ decreases in ammonia contents at 3,6 or 9 storage days compared with unmixed control products. These results indicate the breakdown of protein by proteolysis. The bacterial action on protein may lead to the formation of ammonia. Similarly, (Abu-Salem and Khalaf,1988) showed that the ammonia contents in chicken meat products increased by increasing storage time. Such results agree with those reported by (Demyer and Vandekevchkova, 1979), (El-Deep, 1983), and (Salem et al., 1985).

The lipid oxidation of chicken liver paste was also measured using saponification value (SV). Data in (Table 7) show significant $(P<0.05)$ increases in SV as a result of the storage period at $4{ }^{\circ} \mathrm{C}$. Similar results were reported by (AbuSalem and Khalaf, 1988). These results are due to the hydrolysis of triglycerides and phospholipids by lipases and phospholipases (Aman and Smirnova, 1970). These values were not affected by various treatments. The addition of $1000 \mathrm{ppm}$ of BA or SA or the mixture of $500 \mathrm{ppm}$ of both with or without pasteurization did not affect the SV.

Off odors and the softness of meat texture was noticed by the action of microbial enzymes. Microorganism spoilage caused a breakdown of protein, lipids, pigments and carbohydrates (Schaefer, 2002). The effect of different levels of weak acid preservatives (benzoic acid and sorbic acid) with or without pasteurization to control common micro-organisms causing the spoilage of chicken liver paste (foie gras) was studied and the data presented in Table 8. All treated or untreated samples were free from coliform, Staphylococcus aureus, and Salmonella, which was an index of good sanitory conditions created during processing. On the other hand, aerobic bacteria, mold, and yeast were detected at levels of $10^{4}, 10^{2}$, and 10 c.f.u/g, respectively in control samples at time zero . After nine days of storage at $4{ }^{\circ} \mathrm{C}$, the microorganisms increased which were recorded $10^{5}, 10^{4}$, and $10^{3}$ with aerobic bacteria, mold, and yeast, respectively. The addition of 1000 ppm of BA or SA or the mixture of 500 ppm of both BA plus SA decreased the levels of micro-organisms and these effects increased with pasteurization at $85^{\circ} \mathrm{C}$. This findings indicate that 500 ppm of both BA plus SA with or without pasteurization may be a suitable preserving agent to inhibit the deterioration of chicken liver paste (foie gras). Organic acids have been used for years due to availability, ease of use and low cost. Both benzoic and sorbic acid have a broad spectrum of activity (Nielsen and de Boer, 2000; Davidson, 2001). Benzoic acid and sodium benzoate are most commonly used to prevent the growth of yeasts and molds (Deis, 2002; Davidson and Harrison, 2002). However, bacteria are quite variable in their resistance to benzoate. Benzoate are used primarily as antifungals because: (1) they function best in the undissociated state, which is the predominant from of the compound at low $\mathrm{pH}$ in high acid foods; and (2) fungi are the primary spoilage microorganisms in acidic foods. Therefore, the innate resistance of yeasts and molds to benzoate is of greater concern than that of bacteria (Davidson and Harrison, 2002). Sorbic acid is widely used to inhibit yeast and mould growth and selected bacteria in a variety of foods (FDA, 2002). The minimum inhibitory concentration for many fungi and bacteria are approx. $100 \mathrm{ppm}$ and the common usage levels range from $0.5-1.0 \%$ (FDA, 2002). Besides, the pasteurization of meat destroys vegetative pathogenic and reduces spoilage microorganisms to very low levels. Further studies have to be done in order to adjust the minimum inhibitory concentration necessary to obtain a product with the required shelf life. El-Moueffak et al., (1995) reported that a pasteurization type effect (drastic reduction of vegetative mesophilic and psychrophilic contamination, destruction of Coliforms, and Staphylococcus aureus) was obtained at $50{ }^{\circ} \mathrm{C}$ with samples of duck foie gras pasteurized at $400 \mathrm{MPa}$ for at least $10 \mathrm{~min}$. On the other hand, (Zuber, 1996) showed that pasteurization of foie gras at $60-100{ }^{\circ} \mathrm{C}$ resulted in Coliform, Staphylococcus aureus, and Salmonella absence. However, microorganism aerobic was $10^{4} / \mathrm{g}$ in pasteurized. Potassium sorbate was found to be the most effective in preventing fungal spoilage of bakery products at the maximum concentration (0.3\%) tested (Guynot et al., 2005). In addition, (Okolocha and Ellerbroek, 2005) reported that acids ( $1 \%$ lactic acid or/and ascorbic acid) are viable tools for the decontamination (Enterobacteriaceae, Pseudomonas, and Lactobacillus) of poultry carcasses.

The sensory evaluation showed that liver paste from chicken was very much acceptable from the standpoint of taste, odor, appearance, color and texture. Wherefore, statistical analysis proved that no significant differences have been observed between liver paste (foie gras) from chicken or duck (Table 9). The panelists reported that the taste and flavor of foie gras from both chicken and duck livers were delicate and strong as well as rich in aroma. Appearance and texture were homogenized and creamy in both foie gras. The color was ivory white in duck foie gras and yellow in chicken foie gras. At its best, it is a delicate rosy color with a mottling of beige. The flavor is extraordinarly rich and the texture silky smooth (Epicurious Food Dictionary, 1995). 
Table 9

Sensory evaluation of liver paste (foie gras) manufactured from chicken liver (Mean \pm SD)

\begin{tabular}{ccccccc}
\hline Type & Taste & Odor & Appearance & Color & Texture & $\begin{array}{c}\text { Overall } \\
\text { acceptability }\end{array}$ \\
\hline \multirow{3}{*}{ Chicken liver } & $8.6^{\mathrm{a}}$ & $8.5^{\mathrm{a}}$ & $8.8^{\mathrm{a}}$ & $8.5^{\mathrm{a}}$ & $8^{\mathrm{a}}$ & $\begin{array}{c}8.8^{\mathrm{a}} \\
\pm\end{array}$ \\
& \pm .31 & 0.28 & 0.21 & 0.26 & 0.32 & 0.20 \\
Duck liver & $9.0^{\mathrm{a}}$ & $8.8^{\mathrm{a}}$ & $9.1^{\mathrm{a}}$ & $9.0^{\mathrm{a}}$ & $9.0^{\mathrm{a}}$ & $9.0^{\mathrm{a}}$ \\
& \pm & \pm & \pm & \pm & \pm & \pm \\
\hline
\end{tabular}

Means of scored according to 10 - point hedonic scale (10-9) = very good, (1-0) = very poor.

\section{CONCLUSIONS}

It could be concluded that, liver is an economic and rich source of essential nutrients like protein, iron and zinc. Liver paste (foie gras) from chicken liver were rich in protein and fat (from butter) as well as different minerals, such as $\mathrm{Fe}, \mathrm{Zn}, \mathrm{Cu}$, and $\mathrm{Mn}$. Presumably, the mixing of liver paste (foie gras) from chicken liver with 500 ppm of both benzoic acid plus sorbic acid and pasteurized the product at $85{ }^{\circ} \mathrm{C}$ could be recommended for lowering TBA, TVN, PV, FFA, ammonia, saponification value (SV) and hence for inhibiting lipid oxidation and preventing rancidity to an extent up to nine days of refrigerated storage at $4{ }^{\circ} \mathrm{C}$. This level may be also a suitable preserving agent to inhibit bacterial deterioration of chicken liver paste (foie gras). Sensory evaluation showed that liver paste from chicken liver was very much acceptable. Wherefore, the statistical analysis proved that no significant differences observed between foie gras from chicken or duck liver.

\section{REFERENCES}

Abou-Arab AAK. 2001. Heavy metal contents in Egyptian meat and the role of detergent washing on their levels. J. Food and Chemical Toxicology 39, 593-599.

Abu-Salem FM, Khalaf HH. 1988. Changes of microbiological and chemical properties of chicken meat products (fine chest, sausage and luncheon) during frozen storage at $\left(-18^{\circ} \mathrm{C}\right)$ for 10 months. Ann. Agric. Moshtohor 26 2617-2626.

Abu-Salem FM, Khallaf HH. 1988. Preservation of chicken fat at low tempearature in presence of antioxidants. Annals Agric. Sci. Fac. Agric. Ain Shams. Cairo, Egypt. 33, 115-1130.

Aman ME, Smirnova GA. 1970. Studies on the lipids of pike muscles by TLC. J. Alex. Agric. Res. 26, 197-205.

A.OA.C. 1995. Official Methods of Analysis". A.O.A.C.. International, Suite 4002200 Wilson Boulevard Arlington, Virginia, 2201-3301, USA

APHA. 1992. American Public Health Association Compendium of Methods for the Microbiological Examination of Foods. APHA, pp.7-97, 239-250, and 325-422.

Blum PJC. 1997. "Foie gras" Development in birds: physiological and biochemical characteristics. Acad. Agric. Fr. 83, 101-115.
Branen AL. 1979. Interaction of fat oxidation and microbial spoilage in muscle foods. Food Sci, \& Tech. 156-161.

Davidson MP. 2001. Chemical preservatives and antimicrobial compounds. In Food microbiology: Fundamentals and frontiers. Edited by M.P. Doyle, L.R. Beuchat \& T.J. Montville, pp. 593-627. ASM Press Washington, USA.

Davidson MP, Harrison MA. 2002. Resistance and adaptation of food antimicrobials, sanitizers, and other process controls. Food Tech. 56.

Deis RC. 2002. The complexity of shelf-life stability. Food Product Design, February 2002

Demyer DI, Vandekevchkove P. 1979. Compounds determining $\mathrm{pH}$ in dry sausage. Meat Sci. 3, 161-167.

El-Deep SH. 1983. Food quality as determined metabolic by-products of microorganisms. M.Sc. Thesis, Fac. of Agric. Ain Shams Univ., Egypt.

El-Moueffak AH, Christian C, Antoine M, Montury M, Demazeau G, Largeteau A, Roy B, Zuber F. 1995. High pressure and pasteurization effect on duck Foiegras. International J. of Food Sci. \& Tech. $\mathbf{3 0}$, 737-743.

El-Saaid Basuni SS. 1993. Chemistry and technology of fish preservation and processing. "Book', 35-207, Published by Faculty of Agric., Zagazig Univ. A.R.E. (In Arabic).

Epicurean Com. 2005. Chicken liver paste (pate de foie gras) Recipe. Epicurean Com for food and wine lovers, 15/10/2005.

Epicurious Food Dictionary. 1995. The food lover's companion. Foie gras. Epicurious Food Dictionary, Copyright Barron's Educational Services, Inc., 1995.

Estevez M, Cava R 2004. Lipid and protein oxidation, release of iron from heme molecule and colour deterioration during refrigerated storage of liver pàtè. Meat Sci. 68, 551-558.

FDA. 2002. Food and Drug Administration. Department of Health and Human Services. Part 582-Substances generally recognized as safe-chemical preservatives. Sec. 582-3640.

Fishwish MJ. 1968. Changes in lipids of turkey muscle during storage at chilling and freezing temperature. J. Sci. Food and Agric. 19, 440-445.

Gray JI, Monahan FT 1992. Measurement of lipid oxidation in meat and meat products. Trends Food Sci. Tech. 3, 315-319.

Guy G, Rousselot PD, Gourichon D. 1991. Comparison des performances quantitativees et qualitatives due gavage de l'oie, du canard mulard et du canard de Barbarie. Jounees de recherches avicoles, Tours, 28 April 1993, 99-105, INRA Station de Recherches Avicoles, Nouzilly. 
Guynot ME, Marin S, Sanchis V, Ramos AJ. 2005. An attempt to optimize potassium sorbate use to preserve low pH (4.5-5.5) intermediate moisture bakery products by modelling Eurotium spp., Aspergillus spp. and Penicillium corylophilum growth. International J. Food Microbiology 101, 169-177.

Hecht H. 1996. Copper in the muscles and livers of calves and other mammals. Fleischwirtschaft. 76, 492-494.

Jorhem L, Matterson P, Slorach S. 1984. Lead, cadmium, zinc and certain other metals in foods on the Swedish Market. Var Főda, 36 (suppl.3), 139-208.

Nielsen PV, Boer E. 2000. Food preservatives against fungi. In Introduction to food and airborne fungi. Edited by RA, Samson ES, Hoekstra JC, Frisvad \& O. Fittenborg. pp. 357-363. Centraallureau Voor Schimunelcultures. Utrecht, The Netherlands.

Pearson D. 1976. The Chemical Analysis of Foods. $7^{\text {Th }}$ ed. Churchil Livingston: Edinburgh, London, N.Y.

Salem FA, Askar AA,El-Manawaty HK, Khazbak AI, ElDashlouty AA. 1985. Effect of nitrate level on the chemical and microbiological properties of sausage during storage. Egypt. J. Food Sci. 13, 49-56.
Salichon MR, Guy G, Rousselot D, Blum JC. 1994. Composition of the 3 types of Foie gras: goose, mule, duck and muscovy duck foie gras. Ann Zootech. 43, 213-220.

SAS. (1998). SAS/STAT user's Guide Release 6.03 edition. SAS Institute Inc., Cary, Nc, USA.

SCAH. 2005. Scientific Committee on Animal Health and Animal Welfare. Welfar Aspects of the production of foie gras production. Report of the Scientific Committee on Animal Health and Animal Welfare, 10/12/2005.

Schaefer DM. 2002. Fresh beef marketing opportunities due to dietary vitamin E. National Cattle men's Beef Association and the Cattlemen's Beef Board.

Sola S, Barrio, Martin TA. 1997. Essential elements (Mn, $\mathrm{Fe}, \mathrm{Cu}, \mathrm{Zn}$ ) in pork and duck liver paste produced in Spain. Food Additives and Contaminants 14, 135141.

Zuber F. 1996. La pasteurization des foie gras. Viandes Prod. Carnes 17, 151-156.

Recibido: 8/7/08 Aceptado: 16/9/09 